\title{
Petra Sleeman* and Tabea Ihsane Convergence and divergence in the expression of partitivity in French, Dutch, and German
}

https://doi.org/10.1515/ling-2020-0090

\begin{abstract}
This paper focusses on the so-called partitive pronoun in French and Dutch, and the corresponding data in German, a language which is assumed not to have partitive pronouns in its standard, in contrast to certain dialectal varieties. Taking the diverse uses of the French partitive pronoun en as a starting point, we investigate the corresponding constructions in Dutch and German. The ultimate aim of the paper is to develop an analysis accounting for the similarities and differences between these languages in relation to the presence/absence of the partitive pronoun. To reach our objectives, we rely on data collected in a Grammaticality Judgment Test taken by native speakers of French, Dutch and German. We put together theory and experimental data in a crosslinguistic perspective investigating three languages that differ in their uses of partitive elements and formalize the results in a model in which the partitive pronoun can replace different portions of the nominal structure.
\end{abstract}

Keywords: partitivity, (non-)referentiality, DP-structure, partitive pronoun

\section{Introduction}

In French, partitivity, i. e., the relation between a part and a whole/set, can be expressed in various ways: by proper partitive constructions as in (1), by partitive articles as in (2), and by the partitive pronoun en. ${ }^{1}$

1 We are using the term "partitive article" for the morphological elements $d u$, de la, de l', des and are conscious that in partitive examples like (2) $d u$ is not an article but the combination of the preposition de 'of' and the definite article le 'the', as observed by a reviewer. The term partitive article is therefore a misnomer (not mentioning the fact that nominals introduced with this element are often indefinite and not partitive in meaning; cf. Delfitto and Schroten 1991,

*Corresponding author: Petra Sleeman, Department of Linguistics, University of Amsterdam, Amsterdam, Noord-Holland Netherlands, E-mail: A.P.Sleeman@uva.nl

Tabea Ihsane, Département de linguistique, Université de Genève, Rue de Candolle, Genève CH-1211 Switzerland, E-mail: tabea.ihsane@unige.ch

Ә Open Access. (C) 2020 Sleeman and Ihsane, published by De Gruyter. (c))BY-NC-ND This work is licensed under the Creative Commons Attribution-NonCommercial-NoDerivatives 4.0 License. 
(1) a. J'ai bu un verre de ce jus.

'I have drunk a glass of this juice.'

b. J'ai lu deux de tes livres.

'I have read two of your books.'

(2) J'ai bu du lait (qui était dans le frigo).

I have drunk of.the milk that was in the fridge

'I drank from the milk that was in the fridge.'

(3) [Situation: I have bought five apples.]

$J$ 'en ai mangé deux immédiatement.

I EN have eaten two immediately

'I immediately ate two of them.'

In this paper, we focus on examples with the pronoun en 'of.them', as in (3), but also on examples like (4), which contains a partitive pronoun but which is quantitative in interpretation, in the sense that there is no whole/set implied, in contrast to (3).

(4) Combien de frères a-t-elle? Elle en a trois. how.many of brothers has she she EN has three 'How many brothers does she have? She has three.'

As the above examples show, the term partitive pronoun for elements like en is a misnomer. However, in the absence of a better alternative, we will use that term for presentational reasons. By extension, partitivity may refer to contexts/expressions with a partitive pronoun, although the notion can also be used in a broader sense, covering, e.g., also examples such as (1)-(2). The use of the French pronoun en, which is a clitic, has been extensively studied, both from a descriptive and a theoretical point of view (Milner 1976; Pollock 1998; Ihsane 2013). Ihsane (2013) claims that en can replace different portions of the noun phrase. In (3) en pronominalizes a smaller portion of the DP than in (5), which does not contain a quantifier:

among others; see also https://www.uzh.ch/spur/blog/on-the-so-called-partitive-article-infrench/). 
(5) Paul cherche des noisettes. Il en cherche.

Paul is.looking.for of.the nuts he EN is.looking.for

'Paul is looking for (some) nuts. He is looking for some.'

According to Ihsane (2013), en replaces the complement of the numeral in (3), whereas it pronominalizes the whole complement des noisettes '(some) nuts' in (5). The author models the conditions of the use of partitive en in a DP structure in which various uses of en correspond to different portions of the DP, headed by different functional projections.

In Dutch, the standard use of the partitive pronoun er, which is also called quantitative pronoun, is its combination with a quantified indefinite noun phrase in object position, like the French $(4)^{2}$ :

(6) Hoeveel broers heeft ze? Ze heeft er drie. how.many brothers has she she has ER three 'How many brothers does she have? She has three.'

De Schutter (1992) observes that in some Dutch dialects, especially in Belgium, but not in standard Dutch, er can replace the whole indefinite noun phrase, just like French en in $(5)^{3}$ :

(7) Ik koop wel eens postzegels, maar ik verkoop er

I buy sometimes stamps but I sell ER nooit. (dialectal Dutch)

never

'Sometimes I buy stamps, but I never sell any.'

In contrast to some German dialects, standard German does not possess a partitive pronoun like en/er. However, Strobel (2016) shows that standard

2 There exist other types of er in Dutch (cf. Bennis 1986, who identifies four types), like the locative pronoun in (i) (cf. Section 5), from Veenstra et al. (2010):

(i) Hij heeft er het boek gekocht.

he has ER the book bought

'He has bought the book there.'

For a theoretical analysis of the partitive/quantitative pronoun Barbiers $(2005,2017)$ and Corver et al. (2009), among others.

3 For a theoretical analysis of the use of er in Dutch dialects, see, among others,. Kranendonk (2010). 
German uses the pronominalized adjectival pronoun welch- (which can also be used as an interrogative pronoun: welche Frau 'which woman') to express an undefined quantity ${ }^{4}$ :

A: Ich hätte gerne Radieschen. Hast du welche da?

'I would like (some) radishes. Do you have any?'

B: Ja, da sind welche. Warte, ich geb dir welche.

'Yes, there are some. Wait, I'll give you some.'

(Strobel 2016)

Welch- is one of the four strategies of partitive-anaphoric reference in the German language (Glaser 1993). ${ }^{5}$ In this paper, we only discuss this strategy, as it is the one found in contemporary Standard German.

To our knowledge, a relation between French en or Dutch er and the expression of partitivity in German has never been made explicit or investigated in the linguistic literature. One of the goals of this paper is to fill this gap. The perspective is therefore crosslinguistic, but, because of the richness and the variation in the use of the French pronoun en, we will take the limitations and possibilities of this pronoun as our starting point. What we want to know is how the ways in which en is used in French are expressed i) in languages that also possess a partitive pronoun like en/er, and ii) in languages that do not possess such a partitive pronoun. For the first type of languages we study Dutch, and for the second type of languages we take German as a representative, although this does not necessarily mean that other languages behave exactly in the same way. More generally, this paper will contribute to the understanding of the expression of partitivity in Dutch and German, about which relatively little is known, in contrast to French.

Our methodology consists in using and analyzing equivalent Grammaticality Judgment Tasks submitted to native speakers of French, Dutch and German. We will model our results for Dutch and German in DP structures comparable to the one proposed for French by Ihsane (2013). This will enable us to compare the expression of partitivity in the three languages in a proper way.

This paper is structured as follows. In Section 2, we unfold the subtleties of the use of the partitive pronoun in French, and we present Ihsane's (2013)

4 Low/Northern German also use this pronoun, which is spreading into different dialects of German as an alternative to the partitive forms $(d)(\partial) r(\partial / u)$ (Strobel 2013).

5 The other strategies are: genitive pronouns, null anaphora, and the indefinite pronoun ein (cf. also Strobel 2013). 
theoretical modelling that accounts for the various possibilities of its use. In Section 3, we present our methodology and in Section 4 the results of the Grammaticality Judgment Tasks that we submitted to native speakers of French, Dutch and German. Our results are discussed in Section 5 and modelled in DP structures comparable to the one proposed by Ihsane (2013) for French in Section 6. In Section 7, we summarize our findings and make some suggestions for future research.

\section{The use and syntactic analysis of the partitive pronoun in French}

\subsection{The use of en}

Although we call en in the present paper a partitive pronoun, it is also called a quantitative pronoun in the literature, just like Dutch er. Milner (1978) makes a distinction between the quantitative and the partitive pronoun en. While (9a) illustrates the partitive use of en, like (3), (9b) illustrates the quantitative use, like (4). In addition, en occurs in genitive constructions as illustrated in (10) (Milner 1978), which will not be discussed in this paper:

(9) [Situation: Yesterday five students came to see me.]

a. Aujourd'hui j' en ai revu deux (de ces étudiants). Partitive today I EN have seen.again two (of these students)

'Today I saw again two of them.'

b. Aujourd'hui j' en ai aussi vu cinq (d'étudiants). Quantit./Indef. today I EN have also seen five (of students)

'Today, I also saw five.'

(10) a. Jean se souvient de toutes ses erreurs. Genitive Jean REFL remembers of all his mistakes

'Jean remembers all his mistakes.'

b. Jean s' en souvient.

Jean REFL EN remembers

'Jean remembers them.'

In (9a), en has a partitive interpretation, as the two students (sub-set) are part of the five students (set) mentioned in the context. In (9b), in contrast, en is 
indefinite/quantitative as it is about five different, not yet mentioned, students. Such uses are often referred to as quantitative, as they involve a quantifier such as a numeral (cinq 'five' in (9b)). In (10), en replaces the prepositional phrase de toutes ses erreurs 'of all his mistakes' selected by the verb se souvenir 'remember', which takes a complement introduced by the preposition de 'of'.

In standard French, the use of en is compulsory with an indefinite noun phrase introduced by a quantifier in object position. In (9a) and (9b) this is a cardinal number, but it may also be another type of quantifier:

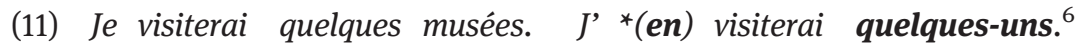

I will.visit some museums I EN will.visit some

'I will visit some museums. I will visit some.'

Furthermore, en is also used in combination with an elliptical noun phrase containing an adjective:

(12) Marie a acheté un ballon bleu. Pierre en a acheté un rouge. Marie has bought a ball blue Pierre EN has bought a red 'Marie has bought a blue ball. Pierre has bought a red one.'

Since en can only be combined with indefinite noun phrases, the use of en with a definite elliptical noun phrase containing an adjective yields an ungrammatical result:

(13) Tristan a vu le petit hôtel. Paul (*en) a vu le grand. Tristan has seen the small hotel Paul EN has seen the big 'Tristan has seen the small hotel. Paul has seen the big one.'

As seen in the introduction, en can also replace some complements with a partitive article, as in (5), repeated below for convenience:

(14) Paul cherche des noisettes. Il en cherche.

Paul is.looking.for of.the nuts he EN is.looking.for

'Paul is looking for (some) nuts. He is looking for some.'

Such examples can be classified into the indefinite/quantitative type, even though there is no quantity expressed overtly. Like other indefinite noun phrases (e. g., with the indefinite article un(e); cf. Fodor and Sag 1982), des-complements

6 Quelques-uns is the pronoun corresponding to quelques when the latter is not directly followed by a noun. 
can be referential or not (Ihsane 2008). In (14), des noisettes is not referential, in contrast to des enfants in (15):

(15) [Situation: You point at Paul and Marie and you say]:

Je vois des enfants sur la plage. Tu (*en)/ les vois aussi?

I see of.the children on the beach you EN/ them see too

'I see children on the beach. Do you also see children/them?'

In (15), the pronoun les refers back to des enfants, which identifies the children as Paul and Marie. The pronoun en cannot have this function, hence the association of en with non-referentiality. En is indeed an anaphoric pronoun which does not involve co-reference with its antecedent (Milner 1978; Lamiroy 1991; Corblin 1995). The fact that en is required in (14) but excluded in (15) shows that there is no perfect correspondence between partitive articles and the partitive pronoun in French: some nominal phrases with a partitive article can be replaced by en, whereas others cannot.

Other constructions of which Ihsane (2013) claims that they can only be nonreferential are negated mass and negated plural indefinites. These can therefore only be replaced by en and not by les:

(16) Anne: $\mathrm{Tu}$ ne bois jamais de vin?

you NEG drink never of wine

Lucie: Non, je n' en / *le bois jamais.

no I NEG EN / it drink never

'Anne: Do you never drink wine? Lucie: No, I never drink wine.'

(17) Pierre: $T u$ n' as pas pris de médicaments aujourd'hui?

you NEG have NEG taken of medicines today

'Didn't you take any medicines today?'

Fred: Non, je n' en ai pas pris/ ${ }^{*} j e$ ne les ai pas

no I NEG EN have NEG taken/ I NEG them have NEG pris.

taken

'No, I did not take any.'

With non-negated mass nouns, too, en is required and the definite pronoun excluded:

(18) Louis: Les chats ont bu du lait ce matin? the cats have drunk of.the milk this morning 
$\begin{aligned} \text { Jeanne: Oui, ils }{ }^{*}(\boldsymbol{e n}) \quad{ }^{*} \boldsymbol{l}^{\prime} \text { ont } \text { on } & \\ \text { yes they EN/ } & \text { it have drunk }\end{aligned}$

'Louis: Did the cats drink milk this morning? Jeanne: Yes, they drank some.'

The various uses of en described in this section have been claimed to be pronominalizations of different portions of the DP structure, as we show in the next subsection.

\subsection{Syntactic analysis}

In her work on en, Ihsane (2013) assumes that this pronoun replaces various constituents headed by de: in genitive and partitive examples like (10) and (9a), en replaces a prepositional phrase headed by the preposition de (19a)-(19b). In indefinite constructions introduced by a partitive article, en replaces the whole noun phrase, including the partitive determiner (19c). In the quantitative construction and the negated NPs, it replaces a portion of the nominal structure containing a functional element de (19d)-(19e). ${ }^{7}$ Examples (19a)-(19d) have been slightly adapted from Hendrick (1985: 178), who does not address constituents with $d u$, for instance:

\begin{tabular}{|c|c|c|c|}
\hline a. Genitive phrase & $\begin{array}{l}\text { le début } \\
\text { the beginning }\end{array}$ & $\begin{array}{l}\text { de ton livre } \\
\text { of your book }\end{array}$ & $\rightarrow$ [de ton livre $]=$ en \\
\hline b. Partitive phrase & $\begin{array}{l}\text { beaucoup } \\
\text { a.lot }\end{array}$ & $\begin{array}{l}\text { de tes livres } \\
\text { of your books }\end{array}$ & $\rightarrow$ [de tes livres $]=$ en \\
\hline c. $d u / d e s \mathrm{NP}$ & $\begin{array}{l}d u / d e s \\
\text { of.the }\end{array}$ & $\begin{array}{l}N \\
\mathrm{~N}\end{array}$ & $\rightarrow[\mathrm{du} / \mathrm{des} \mathrm{N}]=\mathrm{en}$ \\
\hline d. Quantified NP & $\begin{array}{l}\text { beaucoup } \\
\text { a.lot }\end{array}$ & $\begin{array}{l}\text { de } N \\
\text { of } \mathrm{N}\end{array}$ & $\rightarrow[$ de $N]=$ en \\
\hline e. Negated NP & $\begin{array}{l}\text { pas } \\
\text { not }\end{array}$ & $\begin{array}{ll}\text { de } & N \\
\text { of } & \mathrm{N}\end{array}$ & $\rightarrow[$ de $N]=$ en \\
\hline
\end{tabular}

In the previous section, we showed that Ihsane (2013) makes a distinction between two types of des-phrases (19c): referential ones (15) and non-referential ones (14).

7 That de in quantitative examples (e. g., beaucoup de livres 'a lot of books') is not a preposition, in contrast with de in partitive and genitive constructions, is well-known (Milner 1978; among others). For a different analysis of de in partitive constructions see Kupferman (2001) and Carlier and Melis (2006). 
To account for the different uses of en in (19b-e), Ihsane (2013) proposes the layered noun phrase structure in (20). In (20), the layer replaced by en can be -RefP, the projection hosting the partitive article in examples that are non-referential like (14) with des or (18) with $d u$. The layer replaced by en can also be $\mathrm{FP}_{\text {de }}$, in quantitative and negated constructions like (9b) and (16)-(17) respectively ${ }^{8}$ :

$$
(+\operatorname{RefP})>\ldots-\operatorname{RefP}>\mathrm{FP}_{\text {number }}>\left(\mathrm{FP}_{\text {quantity }}\right)>\left(\mathrm{FP}_{\mathrm{de}}\right)>\left(\mathrm{FP}_{\text {count }}\right)>\mathrm{NP}
$$

The structures of the non-referential des noisettes in (14) and of beaucoup de $N$ in (19d) are shown below:

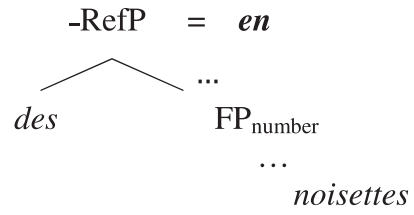

(22)

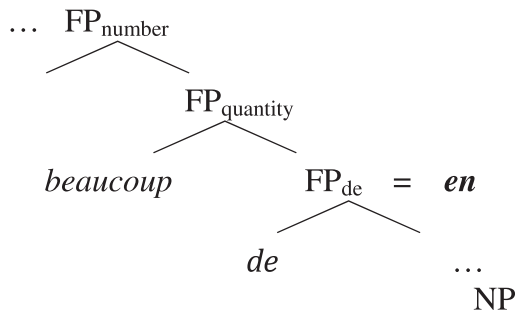

8 Labels adopted from Ihsane (2013: 29). FP stands for Functional Projection and the projections in parentheses represent the ones that are not always projected in the nominal structure. "Number" refers to grammatical number, i. e., singular/plural, whereas $\mathrm{FP}_{\text {quantity }}$ hosts quantifiers such as numerals and beaucoup/peu 'many/few(little)' in its specifier position. As for the projection labelled $\mathrm{FP}_{\text {count }}$, it contains grammatical items leading to an individuated reading (in opposition to the mass interpretation), typically elements like the indefinite article (which then moves higher in the structure) and the plural morpheme on the noun (cf. Borer 2005). + RefP and - RefP represent a split DP, where + RefP would be analogous to Longobardi's (2001) DP encoding referentiality. 
The structure postulated in (22) is also advocated for other quantitative examples, typically with numerals (trois livres 'three books') or with plusieurs 'several' (plusieurs livres 'several books'), the idea being that such examples contain an implicit de 'of'. Evidence for this assumption comes from examples like (23), where de 'of' is overt and where de bonnets 'of hats' is not dislocated. Examples with a dislocated de-phrase like (24) (Lagae 2001) support the presence of $d e$ in the spine of the structure: the dislocated constituent is taken to be a repetition of the constituent replaced by en (Kayne 1977; Milner 1978):

(23) ... ça fait deux de bonnets que je perds. ... it makes two of hats that I lose (Bauche 1951: 79-80 quoted in Kayne 1977: 112 fn.)

(24) J' en ai lu deux / plusieurs, de livres.

I EN have read two / several of books 'I read two/several books.'

The structure in (20) further allows us to capture the contrast between the examples containing a partitive article when it comes to pronominalization (recall (14)-(15)): en can replace -RefP, but not +RefP, which is replaced by a definite pronoun (cf. Gross 1973):

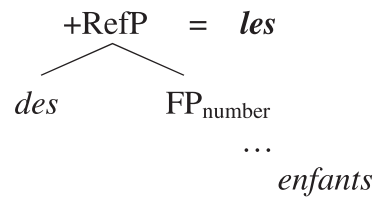

As for the combination of en with an indefinite object noun phrase containing an adjective, as in (12), we adopt Cinque's (2010) analysis, according to which adjectives are merged in the specifier of a functional projection dominating NP, with the NP moving to a higher position to yield a postnominal position of the adjective. Sleeman (1996) shows that only so-called classifying adjectives can be combined with en (Barbaud 1976; Ronat 1977). Just like quantifiers, these adjectives allow de in dislocation, as shown in (26). If the de-phrase reiterates 
what en replaces, as assumed here, it suggests that, in the contexts under discussion, de is present in the structure in (20) (cf. (24)). ${ }^{9}$

(26) J' en ai acheté une rouge, de robe.

I EN have bought a red of dress

'I bought a red dress.'

We therefore propose that the structure can also contain an $\mathrm{FP}_{\mathrm{de}}$ following the adjective:

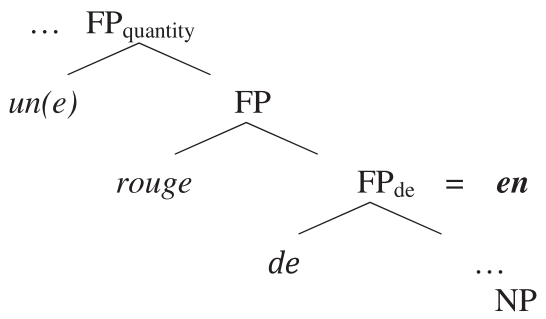

Based on the above discussion, we suggest that the conditions that are necessary but not sufficient for en to be used can be formulated as follows:

(28) a. en replaces constituents headed by de (which can be a preposition or not).

b. en replaces constituents that are not referential (and/or not sub-parts of a referential nominal, cf. (13)).

c. en moves up as a clitic to a verbal host. ${ }^{10}$

In the next section, we present our methodology.

9 As a reviewer observes, this does not imply that all dislocated de-phrases admit a pronoun en:

(i) a. Je ( $\left.{ }^{*} e n\right)$ préfère celle-là, de robe.

I EN prefer this-there of dress

b. Je (*en) préfère la tienne, de robe.

I EN prefer the yours of dress

10 This is a simplification: in imperatives, en follows the verb (Prends-en! 'Take of it!'), and a distinction between finite and non-finite verbs should be made, as en may precede the infinitive (Tu devrais en prendre. 'You should take of it'). 


\section{Methodology}

\subsection{The test}

In Sleeman and Ihsane (2017), we used a Grammaticality Judgment Task to test L2 advanced learners' knowledge of the use of en. The test consisted of 92 French items including 8 fillers. ${ }^{11} \mathrm{~A}$ brief context/situation was provided in brackets when necessary, as in the following example:

(29) [Context: I say: Je vois des enfants dans la cour.

I see of.the children in the yard

Ce sont Julie, Pierre et Sophie.]

these are Julie, Pierre and Sophie

'I see some children in the yard, namely Julie, Pierre and Sophie.'

[Situation: You also see Julie, Pierre and Sophie.]

$\mathrm{Tu}$ dis: J' en vois aussi.

you say I EN see also

'I also see some.'

\section{o Correct \\ o Incorrect}

Several variants of the items were presented in the test, with different targets for which the participants had to decide if they were correct or incorrect. ${ }^{12}$ For (29), for instance, there was also a version in which the students were asked if the option Je les vois aussi 'I also see them' is correct or not.

For the present paper, we used the results of 54 of the 92 test items. We were interested in the following topics:

A. The relation between partitivity and indefiniteness.

B. The relation between partitivity and non-referentiality.

C. The relation between partitivity and quantification.

D. The distinction between a quantitative and a partitive reading.

11 Since the test contained many varied test items, illustrating different uses of en, containing other pronouns, no pronoun or an NP, we considered that they were different enough not to trigger an accommodation effect and did not use more fillers.

12 In the introductory test that we presented to the participants it was made explicit that these terms might be too strong for some cases. 
For A, we analyzed whether our participants accepted the use of (i) en in combination with a definite DP containing an adjective, as in (13). There were 6 items: 3 with en and 3 without en.

For B, we analyzed whether our participants accepted the use of (ii) en in combination with a non-referential plural noun phrase, as in (14), and rejected the use of (iii) en with a referential noun phrase, as in (15). We also tested the acceptance of (iv) en with indefinite mass nouns, as in (18), which are nonreferential. In the three cases, there were 6 items, half of them contained en and half of them $l e(s)$ 'it'/'them'.

For C, we analyzed the acceptability of the use of (v) en with an indefinite noun phrase in object position introduced by a quantifier, as in (11). There were 6 test items, half of which contained en, and half of which contained only the elliptical noun phrase but no en. Since classifying adjectives also create subsets, just like quantifiers, and therefore in a sense may be related to quantification (Sleeman 1993), we analyzed the acceptance of the use of (vi) en with a classifying adjective in an indefinite noun phrase, as in (12). There were 6 items, 3 with and 3 without en. Since negation can also count as a quantifier, we analyzed the acceptance of the use of (vii) en with negated singular and plural noun phrases, as in (16) and (17). Negated noun phrases are always non-referential. Therefore, they can also be used for B. For each category, there were 6 items, half of which contained en and half of which contained le or les.

For D, we analyzed the acceptance of (viii) en in quantitative contexts, as in (9b), and in partitive contexts, as in (9a). For both categories, there were 3 sentences.

Since we were interested in the expression of partitivity (in a broad sense as explained above) in other languages, with and without a partitive pronoun such as en/er, we created a test in Dutch and a test in German, with sentences similar to the French ones. In the German test we used welch- in a part of the sentences, cf. (8), viz. those in which en replaces a constituent without an overt quantifier (i. e., $d u / d e s$ constituents and negated mass/plural indefinite noun phrases). In the Dutch and the German tests, we gave, for some categories, three variants instead of two: er (Du)/Ø (Ger), definite pronoun, noun. The third option is illustrated below:

(30) [Context: Isabelle: Haben Sie sich Zucker von Ihrem Nachbarn have you yourself sugar of your neighbour geliehen?]

borrowed

'Did you borrow sugar from your neighbour?' 
Mélanie: Ja, er hat mir Zucker geliehen.

yes he has me sugar lent

'Yes, he has lent me sugar.'

For the quantitative versus partitive interpretation there were 9 items in German and Dutch instead of 6 . The reason is that the partitive interpretation can also be expressed in these languages by means of a pronominal adverb, davon in German and ervan in Dutch.

(31) [Situation: Yesterday I saw five students.]

Vandaag heb ik twee ervan opnieuw gezien. Pron. adv. ervan today have I two of.them again seen

'Today I saw two of them again.'

For negated singular and plural noun phrases in German, we added 4 sentences containing the negator kein-:

(32) [Context: Louis: Haben sie kein Geld?]

have you no money>

'Don't you have money?'

Sara: Nein, ich habe keins.

no I have none

'No, I don't have any.'

For Dutch, we wanted to know if er is also only accepted in indefinite contexts, if it is accepted in non-referential contexts but not in referential contexts, if it is related to quantification in the same way as French en, and if both a partitive and a quantitative interpretation are accepted for er.

What interested us for German was to know if, in spite of the absence of a partitive pronoun like en, German is able to express partitivity in the same way as French, if a distinction between a quantitative and a partitive interpretation can be made, and a distinction between a referential and a non-referential reading.

The Dutch test had been created to test the knowledge of er of the Dutch L2 learners of French tested in Sleeman and Ihsane (2017), because we were interested in transfer in L2 acquisition. The Dutch test contained 88 questions including 16 fillers. For the purpose of this paper, we used the results of 72 test items, excluding the fillers, for the same categories as the ones specified above for French:

(i) er with a definite article + adjective (6 items for Dutch)

(ii) er with non-referential plural indefinites (9 items for Dutch)

(iii) er with referential plural indefinites (9 items for Dutch) 
(iv) er with indefinite mass nouns (9 items for Dutch)

(v) er with quantified noun phrases (6 items for Dutch)

(vi) er with an indefinite article + adjective (6 items for Dutch)

(vii) er with negated singular and plural indefinites (18 items for Dutch)

(viii) er with a quantitative or a partitive interpretation (9 items for Dutch)

The German test was created for the purpose of the present paper. It contained 82 test items including 15 fillers. We tested whether partitivity can also be expressed in the absence of a partitive pronoun. We also tested whether welch- can have the same function as en replacing a $d u / d e s-c o n s t i t u e n t$ and a negated mass/plural noun phrase:

(i) Ø with a definite article + adjective (3 items for German)

(ii) welch- with non-referential plural indefinites (9 items for German)

(iii) welch- with referential plural indefinites (9 items for German)

(iv) welch- with indefinite mass nouns (9 items for German)

(v) $\varnothing$ with quantified noun phrases (3 items for German)

(vi) $\varnothing$ with an indefinite article + adjective (3 items for German)

(vii) welch- with negated singular and plural indefinites (22 items)

(viii) $\varnothing$ with a quantitative or a partitive interpretation (9 items for German)

Examples for Dutch and German will be provided with the results in Section 4.

\subsection{The participants}

The French test had been filled in by 8 native speakers of French, who served as a control group in Sleeman and Ihsane's (2017) study on the acquisition of en by Dutch learners of L2 French. ${ }^{13}$ The Dutch test had been filled in, for the same study, by the experimental group, Dutch advanced students of French. On the basis of a questionnaire, we eliminated some participants and analyzed the data of 23 participants: 13 undergraduate students and 10 graduate students. The goal of this test was to study transfer from the use of Dutch er to French.

The German test was filled in by 40 monolingual native speakers of German, mainly living in Germany, but also in the Netherlands and four of

13 Although the number of native speakers of French is rather low, their judgments are consistent and correspond to a high degree to what is described in traditional grammars and the linguistic literature. For reasons of comparability with the results of Sleeman and Ihsane (2017), we decided therefore not to add more participants to the group of French native speakers. This means, however, that we will have to be careful with the interpretation of the statistical analysis that we will present in the next section. 
them living in Switzerland. We have not detected differences in the results of these groups.

\section{Presentation of the results}

In this section, we present the analysis of the data per category, as classified in Section 3.1. ${ }^{14}$

(i) Definite article + adjective

Figure 1 shows that in the three languages an elliptical noun phrase introduced by a definite article and containing an adjective, as in (13) or (33), is accepted by the participants. It is, however, significantly less accepted in Dutch than in French ( $p=0.011)$ or in German ( $p=0.001)$. We will come back to this point in the discussion. If the sentence contains a partitive pronoun, it is not accepted by the native speakers of French $(0 \%)$ nor by the native speakers of Dutch (cf. (13)) vs. ((34)) below) in the test:

(33) [Situation: Julia has chosen the yellow bike from the catalogue.]

Anna hat das grüne aus dem Katalog ausgewählt.

Anna has the green from the catalogue chosen

'Anna chose the green one from the catalogue.'

(34) [Situation: John has caught three hares.]

Hij heeft (*er) de derde in het bos gedood.

he has ER the third.one in de wood killed

'He killed the third one in the woods.'

(ii) Non-referential plural NPs

14 Most of the percentages that we present for French can also be found in Sleeman and Ihsane (2017), but for criterion (viii), we did not make a distinction between the partitive and quantitative interpretations. The Dutch data are analyzed in more detail than in Sleeman and Ihsane (2017). Another difference is that Sleeman and Ihsane (2017) provided percentages in terms of accuracy of acceptance or rejection by the L2 learners of French and the native speakers of French and Dutch, establishing a norm for correctness for each sentence. In the present paper, we give percentages of acceptance of sentences without reference to a norm. This means for instance that whereas in Sleeman and Ihsane (2017) the percentage of (correct) rejection by the native speakers of French for context (i), the combination of en with a definite article and an adjective, is $100 \%$, in Figure 1, the percentage of acceptance is $0 \%$. 


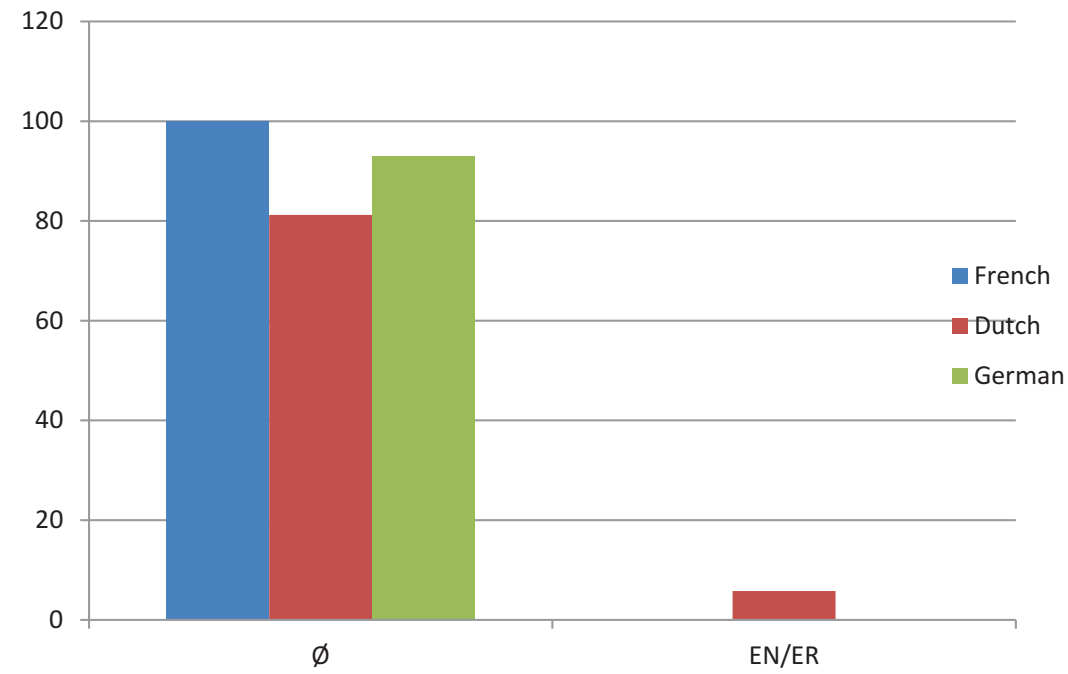

Figure 1: Definite article + adjective.

Figure 2 shows that with non-referential noun phrases the German participants accept welch- (cf. (8)) where in French en is accepted (cf. (14)). In this context the Dutch participants do not accept er (cf. (35)). In Dutch (cf. (35)) the use of the definite pronoun is accepted significantly more than in French $(p=0.001)$ or in German $(p=0.001)$. For Dutch and German, we also investigated whether the participants accepted the use of a full NP (cf. (35c)), which they do, as the figure shows.

(35) [Situation: At the wedding. all guests may take some flowers from a basket to throw at the bride and the bridegroom. Julia decides to throw flowers.] Michelle says:
a. ${ }^{\star} I k$ gooi er ook.
I throw ER too
b. ?lk gooi ze ook.
I throw them too
'I throw them too.'
c. Ik gooi ook bloemen.
I throw too flowers
'I also throw flowers.'

(iii) Referential plural indefinite NPs 


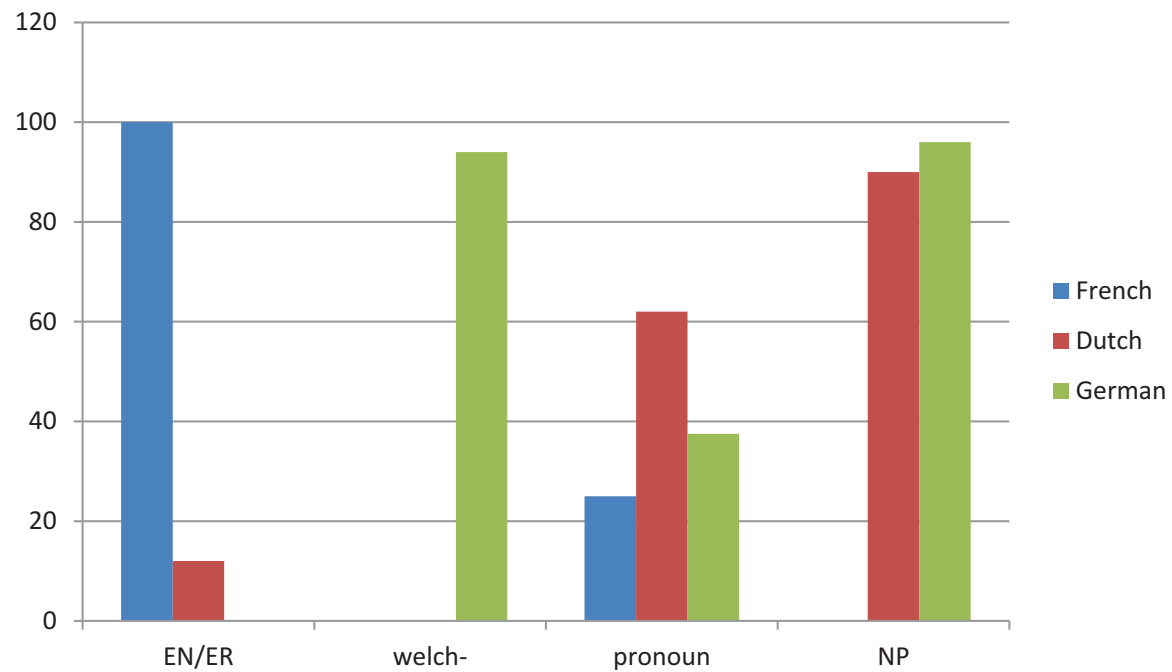

Figure 2: Non-referential plural NPs.

En, er and welch- are not accepted with referential NPs, as Figure 3 shows, but significantly more in French ( $\mathrm{p}=0.002)$, cf. $(15)$, or in German ( $<0.001)$, cf. (36), than in Dutch (cf. (37)). In one of the three sentences of the Dutch and the German test the NP (not tested for French) was preceded by a definite article. The use of a bare NP is less accepted than the use of a definite article, both in Dutch $(\mathrm{p}=0.001)$ and in German $(\mathrm{p}<0.001)$.

(36) [Context: I say: Ich sehe Kinder auf dem Schulhof spielen.

I see children on the schoolyard play Es sind Sara, Paul und Eva.] it are Sara Paul and Eva 'I see some children playing in the schoolyard, namely Sara, Paul and Eva.'

[Situation: You see exactly the same children playing in the schoolyard.]

a. You say: ${ }^{\star} I c h$ sehe auch welche.

I see also some

b. You say: Ich sehe sie auch.

I see them too 


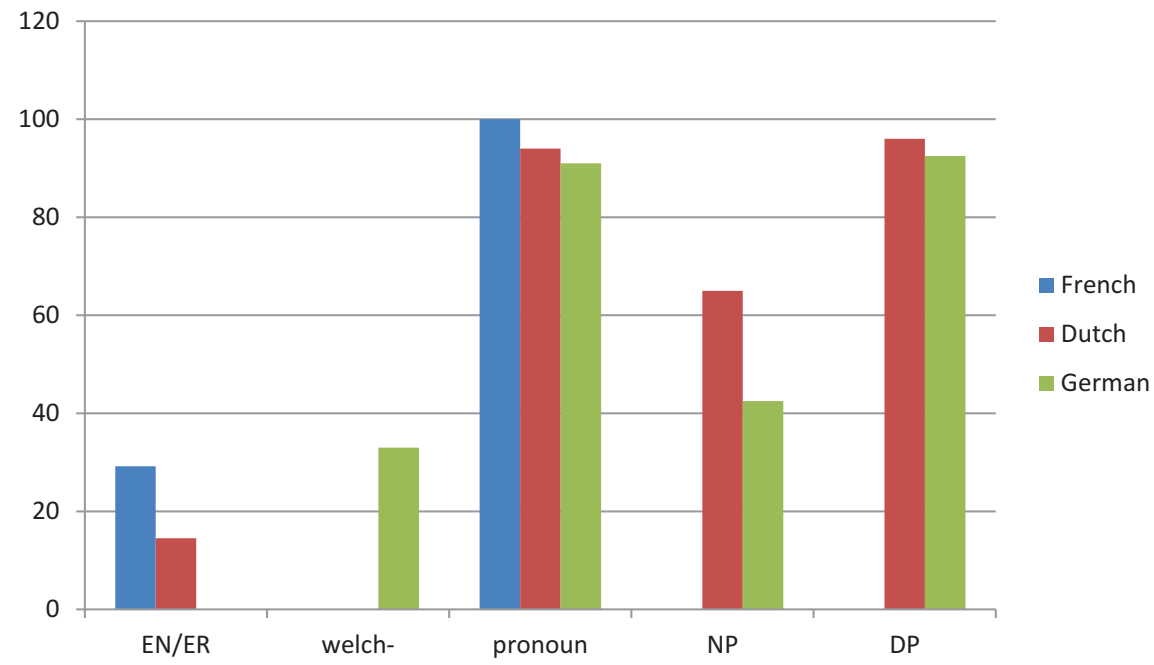

Figure 3: Referential plural NPs.

(37) [Context: I say: Ik zie kinderen op het schoolplein spelen.

I see children on the schoolyard play

Het zijn: Jelle, Fleur en Ina.]

these are Jelle, Fleur and Ina

'I see some children in the schoolyard, namely Jelle, Fleur and Ina.'

[Situation: You see exactly the same children playing in the schoolyard.] You say: Ik zie ze ook.

I see them too

(iv) Mass nouns

As for mass nouns, we see in Figure 4 that whereas the use of en and welch is accepted in French (cf. (18)) and German (cf. (39)), the use of er is not in Dutch (cf. (38)). The use of a definite pronoun is more marginally accepted in German than in Dutch. This difference is significant $(p<0.001)$. In French, it is not accepted $(0 \%)$. The acceptance of the use of NPs was only investigated for Dutch and German (cf. (30)). NPs are accepted for both languages. 


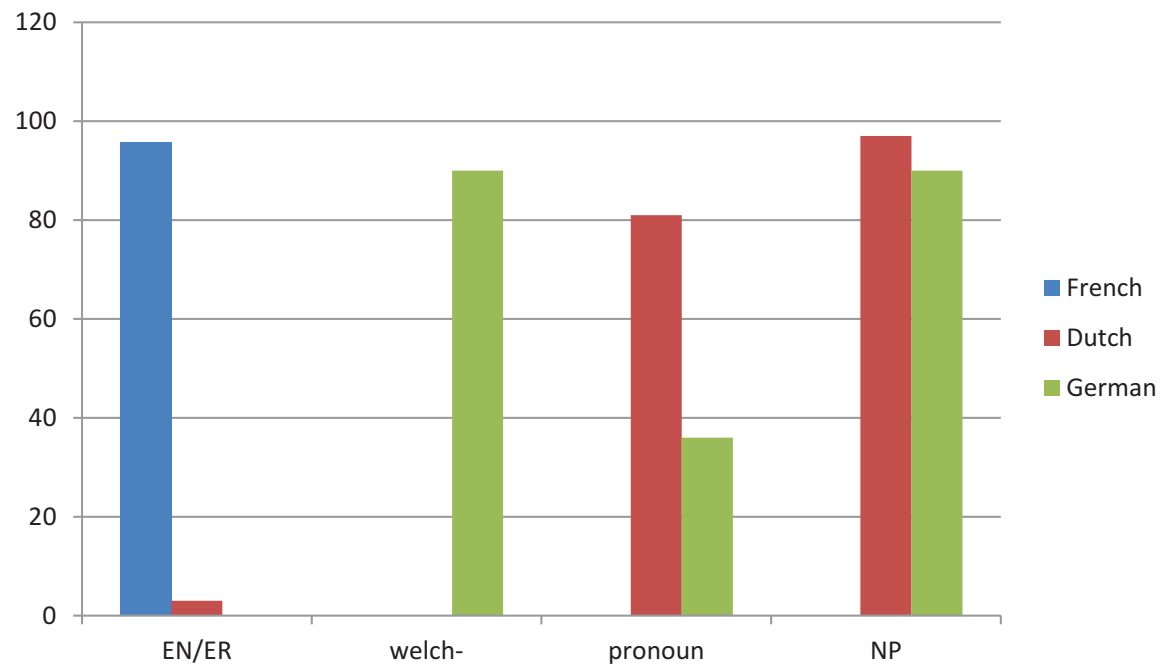

Figure 4: Mass nouns.

(38) [Context: Piet: Hebben de katten melk gedronken vanmorgen?] have the cats milk drunk this.morning 'Did the cats drink milk this morning?'

Anna: Ja, ze hebben het/ melk gedronken. / ${ }^{\star} J a, z e$ yes they have it/ milk drunk yes they hebben er gedronken. have ER drunk

(39) [Context: Child: Könntest du bitte Brot kaufen?] could you please bread buy 'Could you please buy bread?'

Mother: Nein, wir haben noch welches/ wir haben ${ }^{*}$ es noch/ wir no we have still WELCHES we have it still we haben noch Brot. have still bread 'No, we still have bread.' 


\section{(v) Quantified elliptical object NPs}

As illustrated in Figure 5, the use of the partitive pronoun is accepted both in Dutch (cf. (6)), and in French (cf. (11)). The omission of the partitive pronoun is, however, rejected in French (0\% acceptance), as it is in Dutch (15\%), although this difference is significant $(\mathrm{p}=0.041)$. In German, welch- cannot be used in this context (not tested), but the omission of the noun is accepted only in $63 \%$ of the cases (cf. (40)), which is, however, significantly more than in French ( $\mathrm{p}<$ 0.001) and in Dutch ( $<<0.001)$.

(40) [Ich werde einige Museen besuchen.] - Ich werde einige besuchen. I will some museums visit I will some visit '[I will visit some museums.] I will visit some.'

(vi) Indefinite article + adjective

The use of the partitive pronoun in combination with an indefinite elliptical $\mathrm{NP}+$ adjective is accepted by the French participants (cf. (12)), see Figure 6. By the Dutch participants, the omission of the partitive pronoun is preferred (cf. (41)). This also holds for the native speakers of German (cf. (42)).

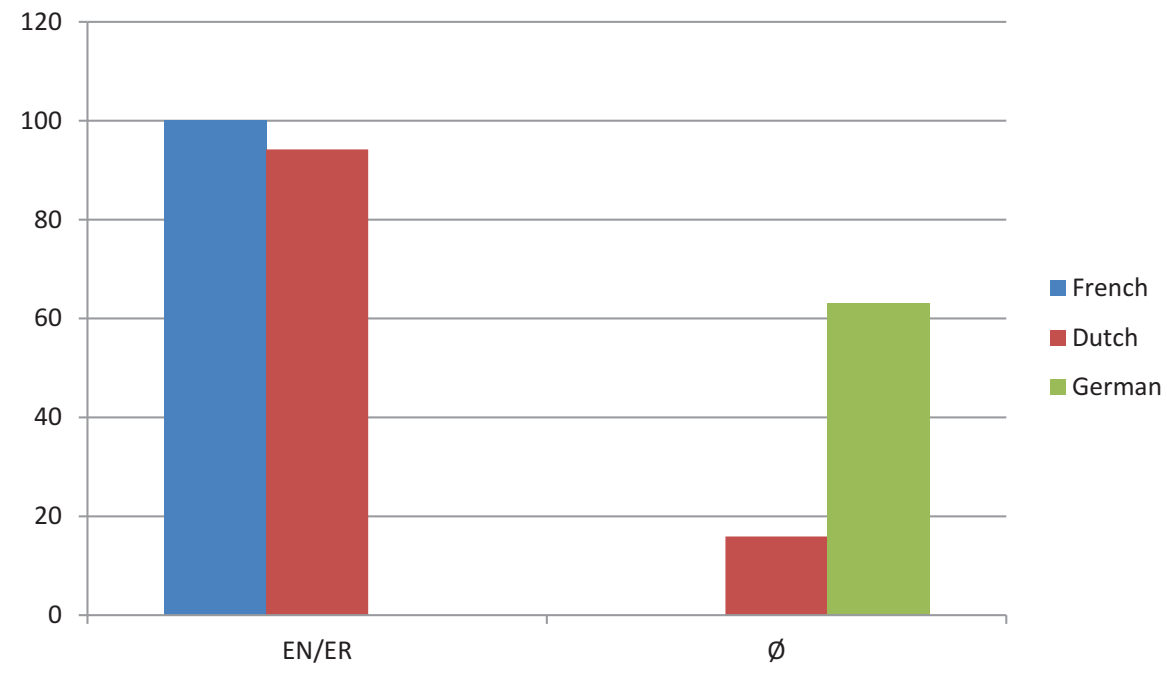

Figure 5: Quantified object NPs. 


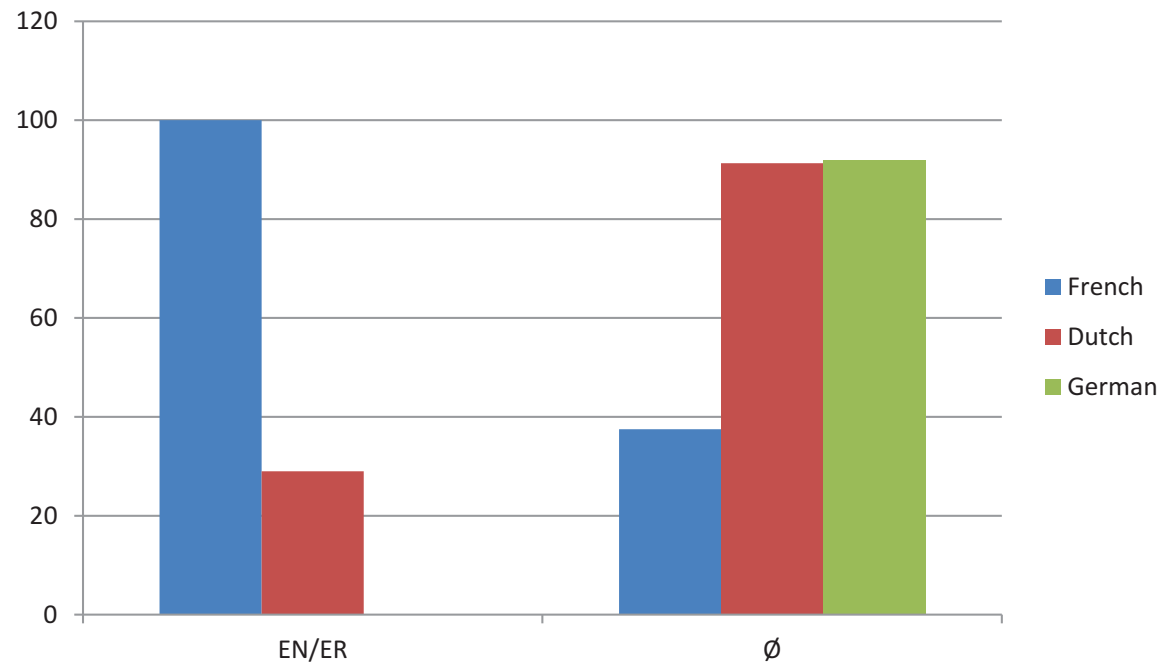

Figure 6: Indefinite article + adjective.

(41) [Situation: Marie has bought a blue balloon.]

Paul heeft (*er) een rode gekocht.

Paul has ER a red.one bought

'Paul bought a red one.'

(42) [Situation: Julia has chosen a yellow bike in the catalogue.]

Anna hat ein grünes aus dem Katalog ausgewählt.

Anna has a green from the catalogue chosen

'Anna chose a green one from the catalogue.'

(vii) Negated indefinite singular and plural NPs

In Figure 7, we see that with negated singular elliptical NPs the native speakers of French, cf. (16), and German, (cf. (44)), accept the use of en resp. welch-, but that the Dutch participants strongly prefer the definite pronoun (cf. (43)). The German native speakers marginally accept the use of the definite pronoun. The French native speakers do not accept it at all (0\%). The acceptance of the use of an NP was investigated for Dutch and German, with a positive result. For German, the acceptance of the negator kein- was furthermore tested and yielded a positive outcome (cf. (32)). 


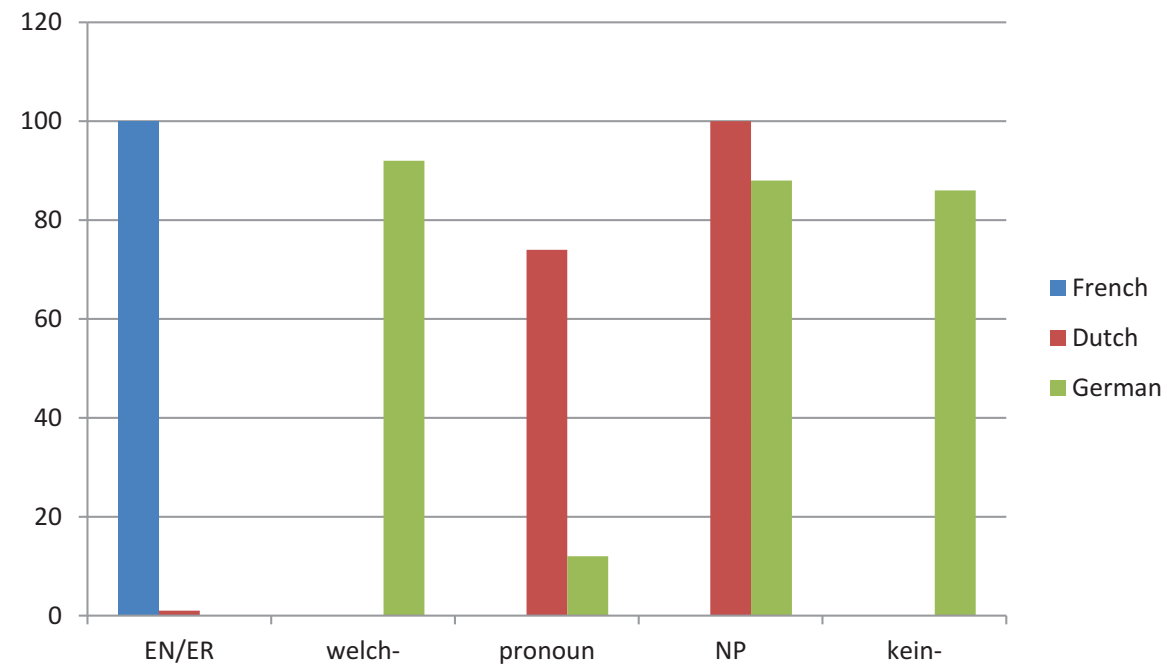

Figure 7: Negated singular elliptical NPs.

(43) Anna: Drink je geen bier?

drink you no bier

'Don't you drink beer?'

Jan: Nee, ik drink *er niet. / Nee, ik drink het niet/ Ik drink no I drink ER not no I drink it not I drink geen bier.

no beer

'No, I do not drink any.'

(44) Ann: Trinken Sie keinen Wein?

drink you no wine

'Don't you drink wine?'

Lucie: Nein, ich trinke nie welchen.

no I drink never WELCH

'No, I never drink any.'

A similar result is provided in Figure 8 for negated plural NPs, but the acceptance of welch- in this context is significantly lower than the acceptance of en 


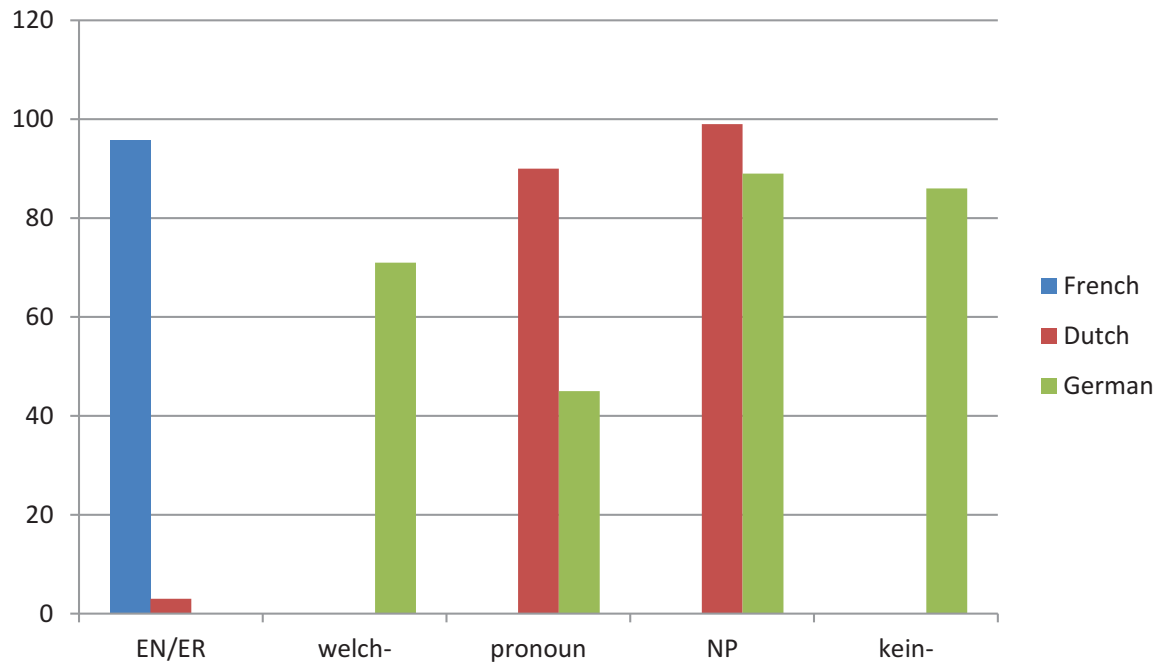

Figure 8: Negated plural elliptical NPs.

( $\mathrm{p}<0.001)$ and also than the acceptance of welch- with negated singular NPs ( $\mathrm{p}<0.001) .{ }^{15}$ We will come back to this point in the discussion section.

\section{(viii) Quantitative or partitive interpretation}

According to Figure 9, the quantitative interpretation is accepted by the participants for both en (cf. (9b)) and er (cf. (45b)) below), but also, although to a minor degree, in German, which does not use welch- in this context, the distinction is made (47). This also holds for the partitive interpretation (cf. (9a), (45a)), even though in both

15 The welch- sentences consisted of two sentences containing nie(mals) 'never', and one control sentence containing nicht 'not'. The control sentence served to establish that the combination of welch- with nicht is ungrammatical: sentence (i) was rejected by all native speakers of German. The percentage of acceptance given in Figure 8 is based on the two sentences containing nie(mals), one of which is illustrated in (ii):

(i) [Context: Fred: Haben sie heute Morgen keine Medikamente genommen?]

have you today morning no medicines taken

Patrick: *Nein, ich habe welche nicht genommen.

no I have WELCHE not taken

[Fred: Haven't you taken any medicines this morning?] - Patrick: 'No, I haven't.'

(ii) Liest du niemals Kriminalromane? Nein, ich lese nie welche. read you never thrillers no I read never WELCHE

'Do you never read thrillers? No, I never do.' 


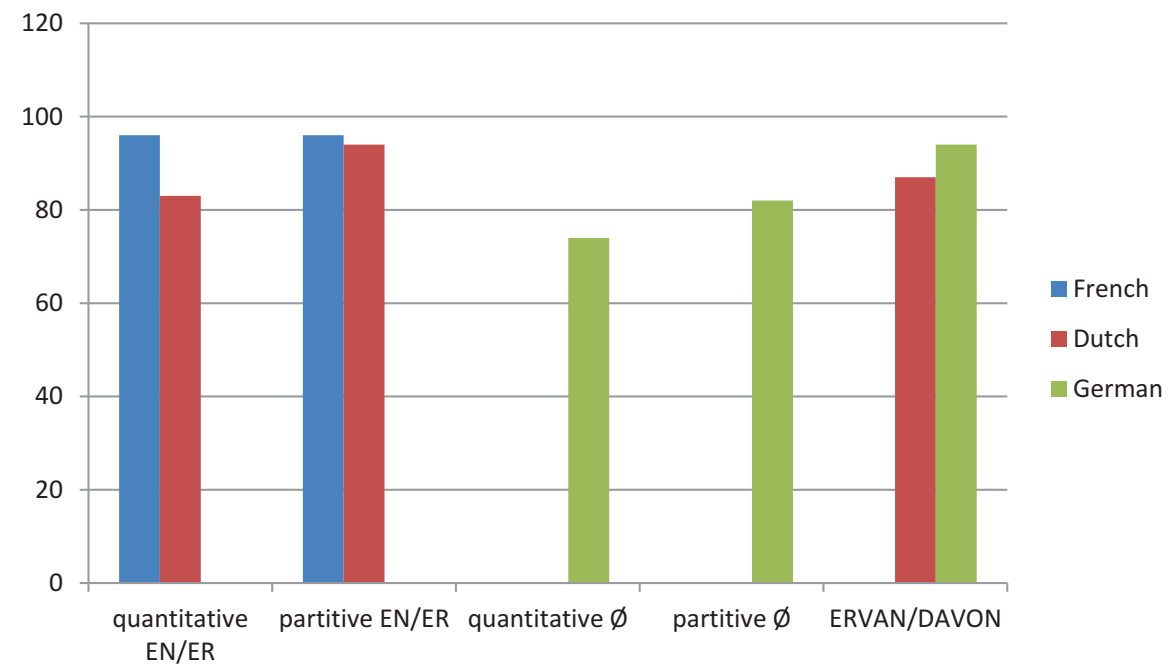

Figure 9: Quantitative or partitive interpretation.

Dutch (cf. (31) and (45a)) and German (cf. (46)) the partitive interpretation can also be expressed by a pronominal adverb: ervan/davon. German does not significantly differ from French or Dutch in these three contexts.

(45) [Situation: Yesterday I saw five students.]

a. Vandaag heb ik er twee/twee ervan opnieuw Partitive er today have I ER two/two of.them again gezien.

seen

'Today I saw two of them again.'

b. Vandaag heb ik er ook vijf gezien. Quantitative er today have I ER also five seen

'Today I also saw five (students, i.e., different students).'

(46) [Situation: Last year we built fifty houses.]

Gestern haben wir zwei/zwei davon Pron. adv. davon yesterday have we two/two of.them abgerissen, weil sie schlecht gebaut waren. torn.down because they badly built were 
(Also gibt es jetzt noch 48 Wohnungen.)

therefore gives it now still 48 houses

'Yesterday we tore down two houses because they were badly built. This means that there are 48 houses left.'

(47) [Situation: Yesterday we tore down two houses because they had been badly constructed.]

Heute haben wir drei abgerissen. Quantitative interpretation today have we three torn.down

'Today we have torn down three houses.'

\section{Discussion}

Besides a crosslinguistic comparison of the possibilities to express partitivity in the three languages under study, our test has allowed us to compare alternative constructions within the languages. Furthermore, we have not provided the intuitions of one native speaker per language, as is often done in the linguistic literature (often these are the author's intuitions) nor have we simply copied judgments provided in grammars or the linguistic literature. For French we have checked judgments reported in the literature by means of a Grammaticality Judgment Task. For Dutch and German, we have provided very few judgments from the literature beforehand, the reason being that the 8 categories distinguished in Section 3 are barely discussed in Dutch and German grammars and literature. A Grammaticality Judgment Task is an appropriate tool to explore native speakers' intuitions (Blume and Lust 2016) about the possibilities within these categories, which we distinguished on the basis of what has been described for French. Familiarity with this kind of tests or some metalinguistic knowledge may have influenced the results. The Dutch informants were undergraduate and graduate students of French, whereas most of the German participants did not have any notion of linguistics. The French informants were mainly, but not exclusively, linguists. Hereafter we discuss our results. For the reader's convenience, we first represent the results presented in the previous section in Figures 10, 11 and 12 per language. 


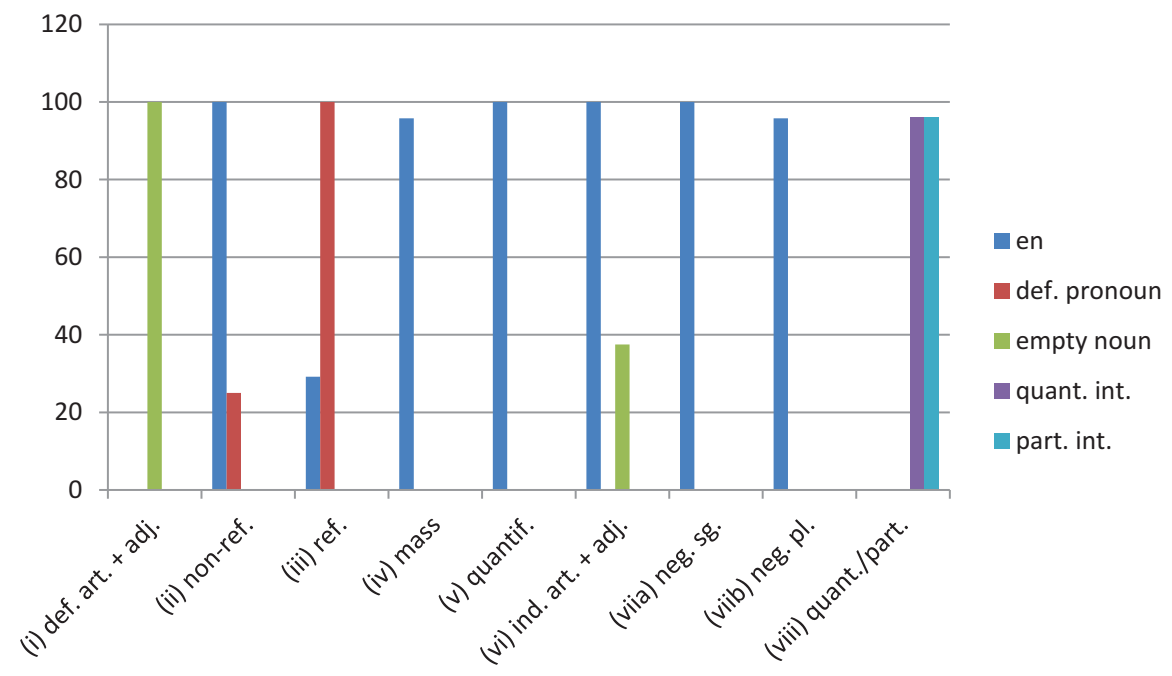

Figure 10: French data.

Category (i): partitive pronoun $0 \%$; (iv) definite pronoun $0 \%$; (v) empty noun $0 \%$; (vi) empty noun $0 \%$; (viia) definite pronoun $0 \%$; (viib) definite pronoun $0 \%$.

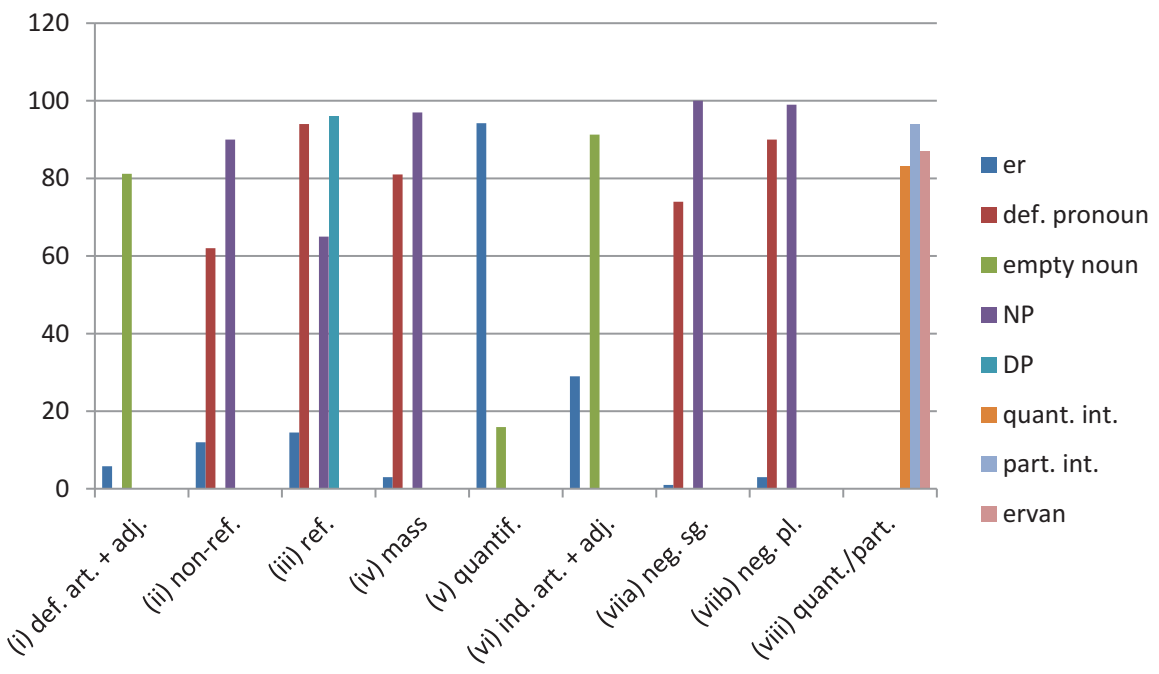

Figure 11: Dutch data. 


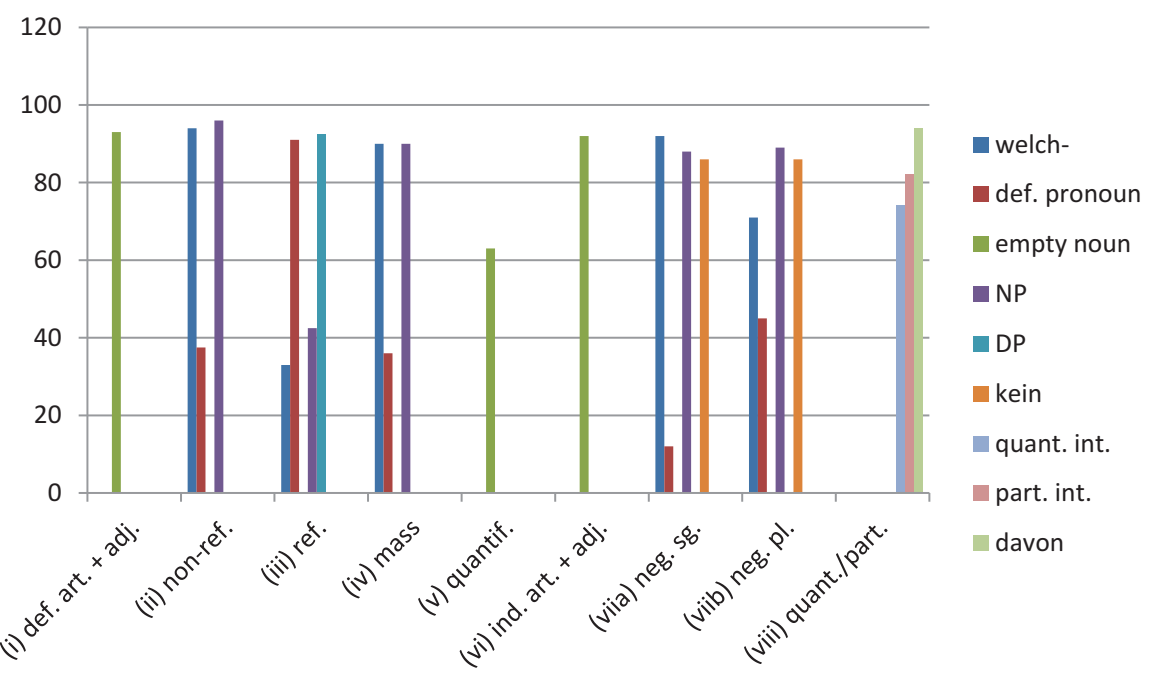

Figure 12: German data.

The context of definite article plus adjective (i) disallows the use of the partitive pronoun; an elided noun is preferred. ${ }^{16}$ The lower acceptance of the omission of the noun in Dutch is due to the relatively low percentage of acceptance of one sentence (44\%), which may be due to another reason than the omission of the noun.

With non-referential plural noun phrases (ii), standard Dutch does not accept er, in contrast to Dutch dialects (cf. (7)), but prefers a definite pronoun, significantly more than German (37,5\%) and French $(25 \%)$.

With referential noun phrases (iii) the use of a definite pronoun or a DP is preferred in the languages under consideration. The use of an NP is less accepted with referential noun phrases than with non-referential noun phrases. In Dutch the use of er is rejected, but the use of en in French and welch-in German is marginally accepted by the native speakers. The reason for this might be that some contexts did not completely exclude the use of a non-referential interpretation. Although the participants were categorical in rejecting (29) and (36) - 0\% acceptance for French and 2,5\% acceptance for German - the other

16 The non-acceptance of $e r$ with a definite article + adjective in Dutch may be related to the non-acceptance of $e r$ with an indefinite article + adjective. It would then be due to the combination with an adjective. In sentences with a definite determiner + quantifier er is not acceptable either: *Ik heb er deze drie in de winkel gekocht 'I have (ER) these three in the shop bought', which shows that er cannot be combined with a definite determiner. 
two contexts may also have favored a non-referential interpretation. In one of the contexts en was accepted in $37,5 \%$ of the cases and welch- in $64 \%$; in the other context en was accepted in $50 \%$ of the cases and welch-in $37,5 \% .{ }^{17}$ Notice however that 13 of the 40 German participants made the referential versus nonreferential distinction in all contexts by accepting welch-in the 3 non-referential sentences and a definite pronoun in the 3 referential sentences. The significantly lower acceptance rate of er in Dutch with respect to en and welch-in referential contexts is due to the fact that er is not accepted in non-referential contexts either. The interpretation of a referential context as a non-referential context will not make the use of er more acceptable.

The results for mass nouns (iv) are the same as for non-referential plural noun phrases, but the use of a definite pronoun in Dutch is more accepted with mass nouns (81\%) than with non-referential plural NPs (62\%). For German the acceptance rate of a definite pronoun for mass nouns (36\%) is comparable to the one for non-referential plural nouns $(37,5 \%)$ and lower than for Dutch (probably because German offers the alternative welch-), but interestingly, we observed a difference among the singular definite pronouns: for es 'it' we observed 2,5\% of acceptance, for ihn 'him' 40\% and for sie 'her' 65\%.

With quantified noun phrases (v) in French and Dutch the partitive pronoun is required according to prescriptive grammar. This is confirmed by our data. In German the omission of the noun is accepted in only $63 \%$ of the cases. If we take into consideration the omission of the noun in other categories under study, the percentage increases. In category (viii) the omission of the noun is accepted for German in $74 \%$ of the cases in the quantitative interpretation and in $82 \%$ in the partitive interpretation. In category (vii) the acceptance of the omission of the noun with the negator kein- is $86 \%$. For the three categories the acceptance of the omission of the noun is on average $77 \%$. The omission of the partitive pronoun is accepted in $15 \%$ of the cases in Dutch, which is a significant difference with French (0\%). This may be due to the choice of the quantifier in two of the sentences, because in the third sentence (with the negator geen 'no') there was $0 \%$ of acceptance. ${ }^{18}$

17 The marginal acceptance of welch- with referential noun phrases may also be related to the acceptance of welch- by 11 of the 40 native speakers of German in the following context, which was used as a filler: [Sophie sieht die Kinder spielen.] - Sophie sieht welche spielen.

18 These two quantifiers (meerdere 'several' and enkele 'some') take the substantivized form meerderen and enkelen if they refer to humans, in which case there are speakers who do not use er (Sleeman 2013, fn. 6). This may have caused the acceptance of meerdere and enkele without er when they refer to objects. 
Whereas in category (vi) for French the use of en with an indefinite article + adjective is accepted, its omission is not completely rejected either. This might be due to the fact that in spoken French, the omission of en is accepted in this context by some speakers of French. Dutch and German accept the simple omission of the noun without a supplier. For Dutch a rate of $29 \%$ of acceptance for the use of er with an indefinite article + adjective is somewhat surprising. In some Dutch dialects, the use of er with an indefinite determiner + adjective is, however, accepted (Sleeman 1998; Kranendonk 2010). Although our participants were probably not speakers of these dialects, the combination of er and indefinite article + adjective may not have shocked some of the participants for this reason. Out of the 23 Dutch participants, 6 accepted 2 or 3 sentences with er. That 7 participants accepted $e r$ in one of the sentences may also be due to other reasons. The small word er may not have been noticed when reading the sentence or it may have been interpreted as a locative er, although we added an explicit locative modifier to the test sentences in order to prevent a locative interpretation of er (cf. fn. 2).

With negated nouns (vii), the three languages behave as in the case of nonreferential nouns and mass nouns. In German, however, welch- is accepted significantly less with plural NPs $(71 \%)$ than with singular NPs $(92 \%) .{ }^{19}$ With the negated plural NPs, the use of a definite pronoun is accepted in $45 \%$ of the cases. This percentage comes close to the percentage of acceptance of the use of the definite pronoun with non-referential plural NPs $(37,5 \%)$. In both cases the definite pronoun is the plural form sie. In the singular, there is a difference between the acceptance rate of a definite pronoun with negated indefinite singular NPs (12\%) and mass nouns (36\%). In the test sentences with a singular negated NP, the pronoun was twice ihn 'him' (22,5\% and 11\% of acceptance respectively), and once the neutral pronoun es 'it' ( $0 \%$ of acceptance). The rate of acceptance of sentences with ihn is lower with a negated indefinite singular

19 Since the use of nicht 'not' is impossible in combination with welch-, we used nie(mals) 'never'. For negated plural NPs there were two sentences containing nie(mals) 'never' and one control sentence containing nicht 'not', cf. fn. 16. The use of nie(mals) may sometimes have sounded unnatural. Sentence (i), in which welch- has a negated plural NP as its antecedent, was accepted by only $47,5 \%$ of the native speakers of German. This has reduced the percentage of acceptance of welch- in the context of negated plural NPs.

(i) [Context: Claire: Als Sie in der Bretagne Urlaub gemacht haben, haben Sie da keine Austern gegessen?]'When you were in Brittany for a holiday, didn't you eat any oysters?'

Paul: Nein, ich habe nie welche gegessen.

no I have never WELCHE eaten

'No, I never ate oysters.' 
NP than with a mass noun. With mass nouns, there was one sentence containing ihn (40\% of acceptance). With mass nouns, the test sentence containing es was accepted in $2,5 \%$ of the cases and the one containing sie, i. e., a feminine singular pronoun, in $65 \%$ of the cases. The differences in the acceptance rates of the different forms of the definite pronouns are intriguing. In future work, we will investigate in more detail the role of gender and number in our results.

For Dutch, the definite pronoun was accepted to an equal rate with singular (mass, negated mass noun) and plural (non-referential, negated) elliptical NPs: $77 \%$ and $76 \%$. In the singular we always used the neutral pronoun het 'it', because, according to Audring (2009), in present-day Dutch common, i.e., non-neuter, mass nouns are replaced by het and not by the masculine pronoun hem 'him' or the feminine pronoun haar 'her'. In our test, het replaced twice a neuter noun and four times a common noun. The percentages of acceptance were comparable: $76 \%$ and $78 \%$ respectively, which corroborates Audring's claim.

In the three languages a distinction between a quantitative and a partitive interpretation is made (viii). The relatively low percentage for the acceptance of the quantitative interpretation in German may be due to the results of one sentence, which was only accepted by $58 \%$ of the participants. $^{20}$

In the next section, we make use of a broader classification to compare our results for the three languages.

\section{Modelling the results}

In Section 3, we grouped our subcategories (i-viii) into four broad categories:
A. The relation between partitivity and indefiniteness (i).
B. The relation between partitivity and non-referentiality (ii-iv).
C. The relation between partitivity and quantification ( $\mathrm{v}-\mathrm{vi}$ ).
D. The distinction between a quantitative and a partitive reading (viii).

20 One of the participants observed that the sentence is only grammatical if ein is stressed: 'one'.

(i) [Situation: Yesterday a/one student came to see me.]

Heute habe ich zwei gesehen.

today have I two seen

'Today I saw two students.' 
Our results show that in all three languages a distinction is made between partitivity, in the broad sense as used in this paper, and indefiniteness (A): en, er and welch- are only used in indefinite contexts.

In addition, the results show that there is a relation between partitivity and non-referentiality (B), at least for French and German: with non-referential plural nouns and with mass nouns en resp. welch- are preferred. Standard Dutch does not make the distinction: the use of the definite pronoun is preferred with both referential and non-referential noun phrases like kinderen 'children' (48), which is ambiguous between the two readings.

(48) [Situation: I see a group of identified children] or [Situation: I see a group of unidentified children.]

Ik zie kinderen op het strand.

'I see children on the beach.'

In French, the use of the definite pronoun is not or marginally accepted with non-referential noun phrases and with mass nouns. This is confirmed by the results of the negated noun phrases, which are non-referential. In terms of Ihsane's (2013) DP structure presented in Section 2.2, this means that the distinction of a non-referential portion of the DP can be overtly expressed in French (en) and in German (welch-):

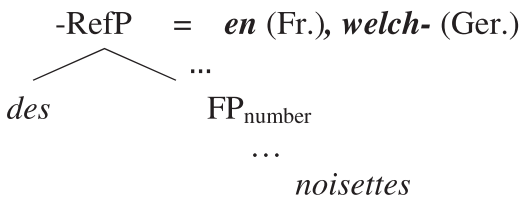

French and German distinguish a non-referential interpretation from a referential interpretation by using a definite pronoun in the latter case:

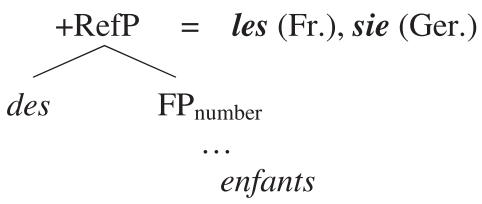

As for Dutch, it is similar to French and German regarding the use of a definite pronoun for the referential interpretation, suggesting that the referential portion 
of the noun phrase can be expressed by a definite pronoun as in (50). ${ }^{21}$ The question that arises is whether Dutch also has a structure like (49) for nonreferential constituents: indeed, since in such examples it is ze that is used, it is not obvious that Dutch has a specific structure for non-referential constituents. However, as kinderen 'children' in (48) can be both non-referential and referential, it shows that Dutch does make a semantic distinction between nonreferential and referential noun phrases. Therefore, we propose that the structure of the former is as in (49), even if the distinction referential/non-referential is not made by means of different pronouns. These cases would be examples of syncretism where an element, like $z e$, is used in different contexts and represents different structures. ${ }^{22}$ The fact that er is not accepted in non-referential constructions may explain the broad acceptance of definite pronouns in Dutch. ${ }^{23}$

Both French and Dutch use a partitive pronoun with a quantifier (C). The corresponding sentences in German have an elided noun. Although the percentage of acceptance is relatively low with quantifiers, the rate of acceptance of an elided noun with the quantifier kein- and in a quantitative or partitive interpretation shows that elision of the noun is a way to express partitivity in German, in the absence of a partitive pronoun. The structure would be as in (51), where $\mathrm{FP}_{\mathrm{de}}$ is restricted to French (in Dutch er replaces the projection selected by the quantifier):

21 In the Dutch Reference Grammar (ANS, Algemene Nederlandse Spraakkunst, Haeseryn et al. 1997) it is observed that in Belgium and the southern part of the Netherlands, er can be used by part of the native speakers of Dutch with a non-referential interpretation and a definite pronoun or a DP with a referential interpretation. These speakers are classified as group $\mathrm{x}$. The other group, group y, does not know the non-referential use of er. Our participants, most of which probably come from the Northwest of the Netherlands, are speakers of "group y".

22 That a "definite" pronoun is not always referential is a known phenomenon: in French for instance, le 'it' can replace a sentence (Je le sais 'I know it') which is not strictly speaking referential. In the same way, a "definite" article is not always definite (prendre le train "take the train'). Such cases are sometimes referred to as weak definites (Aguilar-Guevara and Zwarts 2011).

23 Barbiers (2017) also distinguishes ze from er in Dutch, but from a different perspective. He distinguishes quantitative $z e$, as in (i), from quantitative er:

$\begin{array}{ll}\text { (i) Ik heb ze } & \text { alle twee gelezen. } \\ \text { I have them all tworead } \\ \text { 'I read both.' }\end{array}$

Similarly to our approach, Barbiers argues that pronominalization of Q-ze and pronominalization of Q-er involve different portions of the noun phrase: a higher DP in the case of Q-ze and a lower DP in the case of Q-er. 
(51)

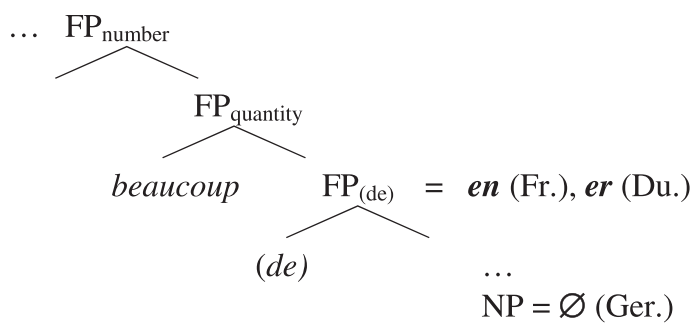

With negated constituents, the results differ from (51): welch- in German patterns with en in French and is accepted, whereas er in Dutch is rejected, as for context (ii). This is not surprising since these constructions are also non-referential (cf. (49)). These results support the fact that $e n$ in French depends on non-referentiality rather than on the quantificational character of the construction or on the underlying presence of $d e$ 'of' and suggests that it is also the case of welch- but not of er. What seems crucial for the use of $\mathrm{er}$ is the presence of a quantifier.

With classifying adjectives, er is often not accepted, suggesting that, in Dutch, classifying adjectives are not as quantifying as quantifiers; otherwise er should be fully accepted since a quantifier seems to be needed for er to be possible. In addition, Dutch allows nominal ellipsis with adjectives, like German. In both Dutch and German, nominal ellipsis depends on the inflectional properties of the adjective (e. g., Muysken and van Riemsdijk 1986; Kester 1996), whereas in French nominal ellipsis with or without en depends on the partitive interpretation of the adjective (Sleeman 1996; Bouchard 2002). In Dutch and German, the $\mathrm{FP}_{\mathrm{de}}$ is not projected.

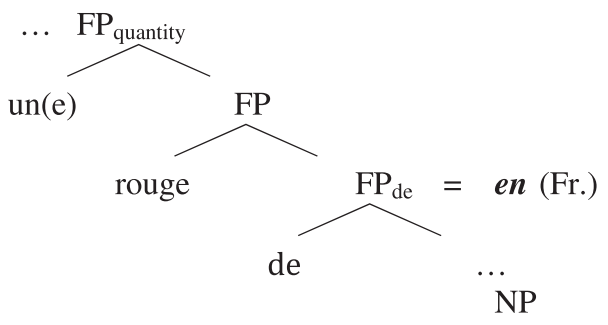

In structure (51), both French en and Dutch er can have a quantitative interpretation and a partitive interpretation (D). Even if in German there is no pronoun, both interpretations are accepted as well.

The above discussion shows that welch-in Standard German is found in the counterparts of the non-referential complements with the partitive article in French. The constructions in which welch-is found are all complete non-referential nominal 
phrases. In other words, welch- cannot replace subparts of the nominal phrase. Er, in contrast, only replaces a portion of the nominal structure, and this only with a quantified element. As for en, it is accepted in both contexts, and also with classifying adjectives.

\section{Conclusion}

In this paper, we have studied the notion of partitivity in a specific way: we have focused on the so-called partitive pronoun en in French and studied eight contexts in which en is accepted or disallowed. Our objective was to find out how other languages, with a similar partitive pronoun like Dutch, or without such a pronoun like German, behave in analogous contexts and to formalize the results in the model developed in Ihsane (2013) in which the partitive pronoun can replace different portions of the nominal structure.

This new crosslinguistic study is based on the results of a Grammaticality Judgment Test taken by native speakers of French, Dutch and German. Our overall finding is that the subtleties of the French partitive pronoun en can also be expressed in Dutch and German, but in partially different ways. Our investigations show that German, which does not have a partitive pronoun such as en or er, often uses no lexical item in the contexts studied, i. e., $\oslash$, where these overt pronouns are found, but that welch- partially has the same function as en, which could mean that standard German does have a partitive pronoun after all. Our results also show that (non)-referentiality correlates with partitivity: non-referentiality can be expressed by a pronoun, both in German and in French, with welch- and en respectively, although the former is much more restricted in the expression of partitivity than the latter. Dutch on the other hand does not explicitly make a distinction between non-referential and referential noun phrases, at least in its standard. Er cannot be used with nonreferential noun phrases. However, our results suggest that definite pronouns are relatively more accepted with referential noun phrases and the repetition of the NP more with non-referential noun phrases. Although German has welch- to express non-referentiality versus referentiality, we found the same tendency for definite pronouns and NPs in German as in Dutch, although to a lower degree. We also observed that Dutch er and the simple omission of the noun in German both allow a quantitative and a partitive interpretation, just like French en. Another finding, on the other hand, is that classifying adjectives allow a partitive pronoun only in French, in contrast to Dutch. In Dutch and German, an elided noun is acceptable, but not in standard French. 
In terms of structure, building on Ihsane (2013), we have proposed that different layers of the nominal structure correspond to different elements in the languages under study. This can be summarized as follows:

(53) a. + RefP = definite pronoun: les (Fr.), sie (Ger.), ze (Du.), cf. (50)

b. - RefP = en (Fr.), welch- (Ger.), possibly ze (Du.), cf. (49)

c. $\mathrm{FP}_{(\mathrm{de})}{ }^{24}=\boldsymbol{e n}$ (Fr.), er (Du.), in quantified examples, cf. (51)

d. $\mathrm{FP}_{(\mathrm{de})}=\boldsymbol{e n}(\mathrm{Fr}$.$) , with a classifying adjective, cf. (52)$

An interesting finding of this paper that deserves more research is the different acceptance rate of the various definite pronouns in non-referential contexts in German. For Dutch it might be furthermore investigated if, in regional varieties, the use of er in non-referential contexts is accepted.

Acknowledgements: We would like to thank Gabrielle Hess, Liliane Klaey, Thom Westveer and Richard Zimmerman, who helped us translate our French test into German. Our thanks also go to Elisabeth Stark and Jasmin Pfeifer, who helped us to pilot the test, and to all the participants. The second author gratefully acknowledges the support of the University Research Priority Program "Language and Space" and of the Romanisches Seminar at the University of Zürich as she was working on this article.

\section{References}

Aguilar-Guevara, Ana \& Joost Zwarts. 2011. Weak definites and reference to kinds. In Li Nan \& David Lutz (eds.), Proceedings of SALT 20, 179-196. Cornell University, Ithaca, NY: CLC Publications.

Audring, Jenny. 2009. Reinventing pronoun gender. Utrecht: LOT publications.

Barbaud, Philippe. 1976. Constructions superlatives et structures apparentées. Linguistic Analysis 2(2). 125-174.

Barbiers, Sjef. 2005. Variation in the morphosyntax of ONE. Journal of Comparative Germanic Linguistics 8. 159-183.

Barbiers, Sjef. 2017. Kwantitatief 'er' and 'ze'. Nederlandse Taalkunde 22(2). 163-187.

Bauche, Henri. 1951. Le langage populaire. Paris: Payot.

Bennis, Hans. 1986. Gaps and dummies. Dordrecht: Foris Publications.

Blume, Maria \& Barbara Lust. 2016. The grammaticality judgment task. In Maria Blume \& Barbara Lust (eds.), Research methods in language acquisition: Principles, procedures, and practices, 155-164. Berlin \& Boston: De Gruyter Mouton.

Borer, Hagit. 2005. In name only: Structuring sense I. Oxford: Oxford University Press.

24 Cf. the discussion around (51). 
Bouchard, Denis. 2002. Adjectives, number, and interfaces. Amsterdam: Elsevier.

Carlier, Anne \& Ludo Melis. 2006. L'article partitif et les expressions quantifiantes du type peu de contiennent-ils le même de? In Georges Kleiber, Catherine Schnedecker \& Anne Theissen (eds.), La relation partie-tout, 449-464. Louvain \& Paris: Peeters.

Cinque, Guglielmo. 2010. The syntax of adjectives: A comparative study. Cambridge, MA: MIT Press.

Corblin, Francis. 1995. Les formes de reprise dans le discours: anaphores et chaînes de référence. Rennes: Presses universitaires de Rennes.

Corver, Norbert, Marjo Van Koppen \& Huib Kranendonk. 2009. Quantitative er: a new microcomparative view on an old puzzle. Paper presented at the 24th Comparative Germanic Syntax Workshop. Brussels: University of Brussels 27-29 May.

Delfitto, Denis \& Jan Schroten. 1991. Bare plurals and the number affix in DP. Probus 3. 155-185.

Fodor, Janet \& Ivan Sag. 1982. Referential and quantificational indefinites. Linguistics and Philosophy 5. 355-398.

Glaser, Elvira. 1993. Syntaktische Strategien zum Ausdruck von Indefinitheit und Partitivität im Deutschen (Standardsprache und Dialekt). In Werner Abraham \& Josef Bayer (eds.), Dialektsyntax, 99-116. Opladen: Westdeutscher Verlag.

Gross, Maurice. 1973. On grammatical reference. In Ferenc Kiefer \& Nicolas Ruwet (eds.), Generative grammar in Europe, 203-217. Dordrecht: Reidel.

Haeseryn, Walter, Kirsten Romijn, Guido Geerts, Jaap de Rooij \& Maarten C. van den Toorn. 1997. Algemene Nederlandse spraakkunst [Dutch reference grammar]. 2nd edn. Groningen: Martinus Nijhoff.

Hendrick, Randall. 1985 The distribution of the French clitic en and the ECP. In Larry D. King \& Catherine A. Maley (eds.), Selected papers from the XIIIth Linguistic Symposium on Romance Languages, Chapel Hill, N.C., 24-26 March 1983, 163-186. Amsterdam \& Philadelphia: John Benjamins.

Ihsane, Tabea. 2008. The layered DP in French: Form and meaning of French indefinites. Amsterdam \& Philadelphia: John Benjamins.

Ihsane, Tabea. 2013. En pronominalization in French and the structure of nominal expressions. Syntax 16(3). 217-249.

Kayne, Richard. 1977. Syntaxe du français: Le cycle transformationnel. Paris: Editions du Seuil.

Kester, Ellen-Petra. 1996. The nature of adjectival inflection. Utrecht: Utrecht University dissertation.

Kranendonk, Huib. 2010. Quantificational constructions in the nominal domain: Facets of Dutch microvariation. Utrecht: LOT Publications.

Kupferman, Lucien. 2001. Quantification et détermination dans les groupes nominaux. In Xavier Blanco, Pierre-André Buvet \& Zoé Gavriilidou (eds.), Détermination et formalisation, 219-234. Amsterdam \& Philadelphia: John Benjamins.

Lagae, Véronique. 2001. J'en ai lu deux, de livres: les structures à détachement de forme de N. In Dany Amiot, Walter De Mulder \& Nelly Flaux (eds.), Le syntagme nominal: Syntaxe et sémantique, 215-231. Arras: Artois Presses Université.

Lamiroy, Béatrice. 1991. Coréférence et référence disjointe: les deux pronoms. En. Travaux De Linguistique 22. 41-65.

Longobardi, Giuseppe. 2001. The structure of DPs: Some principles, parameters and problems. In Marc Baltin \& Chris Collins (eds.), The handbook of syntactic theory, 562-603. London: Blackwell. 
Milner, Jean-Claude. 1976. Réflexions sur la référence. Langue Française 30(1). 63-73.

Milner, Jean-Claude. 1978. De la syntaxe à l'interprétation. Paris: Editions du Seuil.

Muysken, Pieter \& van Riemsdijk. Henk. 1986. Features and projections. Dordrecht: Foris.

Pollock, Jean-Yves. 1998. On the syntax of subnominal clitics: Cliticization and ellipsis. Syntax 1(3). 300-330.

Ronat, Mitsou. 1977. Une contrainte sur l'effacement du nom. In Mitsou Ronat (ed.), Langue, 153-169. Paris: Hermann.

Schutter, Georges de. 1992. Partitief of kwantitatief ER, of over de verklaring van syntactische variatie [Partitive or quantitative ER: On the explanation of syntactic variation]. Taal En Tongval 44. 15-26.

Sleeman, Petra. 1993. Noun ellipsis in French. Probus 5. 271-295.

Sleeman, Petra. 1996. Licensing empty nouns in French. The Hague: Holland Academic Graphics.

Sleeman, Petra. 1998. The quantitative pronoun er in Dutch dialects. In Sjef Barbiers, Johan Rooryck \& Jeroen van de Weijer (eds.), Small words in the big picture: Squibs for Hans Bennis, 107-111. Leiden: Holland Institute of Generative Linguistics.

Sleeman, Petra. 2013. Deadjectival human nouns: conversion, nominal ellipsis, or mixed category? Linguística: Revista De Estudos Linguísticos Da Universidade Do Porto 8. 159-180.

Sleeman, Petra \& Tabea Ihsane. 2017. The L2 acquisition of the French quantitative pronoun en by L1 learners of Dutch: Vulnerable domains and cross-linguistic influence. In Elma Blom, Jeannette Schaeffer \& Leonie Cornips (eds.), Cross-linguistic influence of bilingualism: In honor of Aafke Hulk, 303-330. Amsterdam \& Philadelphia: John Benjamins.

Strobel, Thomas. 2013. On the spatial structure of the syntactic variable 'pronominal partitivity' in German dialects. In Ernestina Carrilho, Catarina Magro \& Xosé Álvarez (eds.), Current approaches to limits and areas in dialectology, 399-435. Newcastle upon Tyne: Cambridge Scholars Publishing.

Strobel, Thomas. 2016. Indefinite-partitive pronouns in the dialects of Hesse. Paper presented at the workshop Partitivity and Language Contact, University of Zürich, 25-26 November.

Veenstra, Alma, Sanne Berends \& van Hout. Angeliek. 2010. Acquisition of object and quantitative pronouns in Dutch. Kinderen Wassen Hem Voordat Ze Er Twee Meenemen. Groninger Arbeiten Zur Germanistischen Linguistik 51. 9-25. 